Article

\title{
Ru nanoparticles supported on hydrophilic mesoporous carbon catalyzed low-temperature hydrodeoxygenation of microalgae oil to alkanes at aqueous-phase
}

\author{
Arif Ali a, Chen Zhao a,b,* \\ a Shanghai Key Laboratory of Green Chemistry and Chemical Processes, School of Chemistry and Molecular Engineering, East China Normal University, \\ Shanghai 200062, China \\ b Institute of Eco-Chongming, East China Normal University, Shanghai 200062, China
}

\section{A R T I C L E I N F O}

\section{Article history:}

Received 28 November 2019

Accepted 23 December 2019

Published 5 August 2020

\section{Keywords:}

Algae oil

Stearic acid

Heptadecane

Hydrophillic carbon

Hydrodeoxygenation

$\mathrm{Ru} / \mathrm{C}$ catalyst

\begin{abstract}
A B S T R A C T
The processing of an energy carrier such as microalgae oil into valuable fuels and chemicals is quite promising. Aqueous-phase processing is suitable for this purpose because the separation of intrinsic water from the algae cell is difficult. In this study, we synthesized ruthenium (Ru) nanoparticles supported on highly hydrophilic mesoporous carbon to catalyze the quantitative hydrodeoxygenation (HDO) of microalgae oil to alkanes in a one-pot process at a low temperature $\left(140^{\circ} \mathrm{C}\right)$ in the aqueous phase. The mesoporous carbon was obtained by single-step calcination of starch and zinc chloride in nitrogen. The as-obtained carbon showed high surface areas and pore volumes, allowing high dispersion of Ru nanoparticles. The surface of the carbon material was rich in hydroxyl groups, as evidenced by X-ray photoelectron spectroscopy (XPS), infrared (IR) spectroscopy, and thermogravimetric analysis (TGA) measurements. As a result, the carbon material contacted preferably with the water phase versus the organic phase, improving the accessibility of substrates. On the other hand, the contact angle test results speculated the superior hydrophilic nature of mesoporous $\mathrm{Ru} / \mathrm{C}\left(\mathrm{ZnCl}_{2}\right.$, starch) than commercial $\mathrm{Ru} / \mathrm{C}$. Both kinetics modeling and in situ IR monitoring in water revealed the superior performance of the hydrophilic mesoporous and hydrophilic $\mathrm{Ru} / \mathrm{C}$ compared to a commercial $\mathrm{Ru} / \mathrm{C}$ for the tandem hydrogenation of stearic acid and decarbonylation of stearyl alcohol. The herein designed hydrothermal carbon material was highly active, environmentally benign, sustainable, and recyclable material, and could be potentially used for other hydrogenation reactions in the aqueous phase.
\end{abstract}

(C) 2020, Dalian Institute of Chemical Physics, Chinese Academy of Sciences. Published by Elsevier B.V. All rights reserved.

\section{Introduction}

Bio-oil from liquefaction of biomass such as algae oil, triglycerides, fatty acids, lignin, and carbohydrates holds great potential to partially replace traditional non-renewable fossil fuels [1-10]. When the bio-oil was directly used in diesel en- gines, for example, algae-derived bio-oil cause engine issues such as carbon deposits, injector coking, and further oil ring sticking due to the high viscosity and high oxygen contents of these compounds $[11,12]$. Thereby, such bio-oil cannot be used directly as a fuel without a previous reduction on metal catalysts [13]. Due to the hydrophilic and polar nature of the multi-

\footnotetext{
* Corresponding author. E-mail: czhao@chem.ecnu.edu.cn

This work was supported by the National Key R\&D Program of China (2016YFB0701100), the National Natural Science Foundation of China (21573075) and Institute of Eco-Chongming (ECNU-IEC-201902).

DOI: 10.1016/S1872-2067(20)63539-2 | http://www.sciencedirect.com/science/journal/18722067| Chin. J. Catal., Vol. 41, No. 8, August 2020
} 
ple oxygen-containing functional groups of triglycerides and derivatives, it is quite difficult to directly separate bio-oil from the water. Thus, aqueous-phase reactions represent promising routes for the conversion of lipid into valuable hydrocarbon bio-fuels.

The selective hydrodeoxygenation (HDO) of lipid was performed using sulfur- and non-sulfur-containing metal catalysts due to their relatively high stability in non-polar phases $[1,14]$. $\mathrm{Ni}$ - and Co- based catalysts are used for the HDO of fatty acids and lipids into alkanes at ca. $260-380{ }^{\circ} \mathrm{C}$ in hydrogen $\left(\mathrm{H}_{2}\right)$ [15-19]. Fatty acids were converted at $65 \%$ conversion into long-chain hydrocarbons at $300{ }^{\circ} \mathrm{C}$ over non-sulfided Pd/Al-SBA-15 in dodecane at 25 bar of $\mathrm{H}_{2}$ [20]. PdNi/HZSM-5 catalyzed the deoxygenation of stearic acid into alkanes via a tandem process at $280{ }^{\circ} \mathrm{C}$ in limonene under a $\mathrm{N}_{2}$ atmosphere [21]. In a recent study [22], $\mathrm{PtIr} / \gamma-\mathrm{Al}_{2} \mathrm{O}_{3}$ catalyzed the deoxygenation of lipid in ethyl-cyclohexane at high temperatures $\left(400{ }^{\circ} \mathrm{C}\right)$ in the absence of $\mathrm{H}_{2}$. However, these deoxygenation reactions have been conducted under drastic temperatures (above $300^{\circ} \mathrm{C}$ ) using polluted solvents.

Porous carbons are attractive materials because of their high surface area, tunable pore structures, and facile functionalization [23,24]. Carbon and N-C supported metal (Ru, Pd, Pt) catalysts have also been applied for HDO of triglycerides and fatty acids into useful chemicals [25-29]. Among them, mesoporous-supported Pd/C achieved $15 \%$ conversion of stearic acid into alkanes at a high temperature of $360{ }^{\circ} \mathrm{C}$ in a $5 \mathrm{vol} \%$ argon- $\mathrm{H}_{2}$ atmosphere [27]. Similarly, $\mathrm{Pd} / \mathrm{C}$ was used for the catalytic deoxygenation of stearic acid in dodecane at $300{ }^{\circ} \mathrm{C}$, achieving $98 \%$ selectivity of alkanes [28]. Compared to reactions carried out in dodecane, non-solvent reaction systems showed slower decarboxylation rates on fatty acids over $\mathrm{Pt} / \mathrm{C}$ at $350^{\circ} \mathrm{C}[29]$. Since water is ubiquitous in biomass and a green solvent, allowing easy bi-phasic separation of insoluble alkanes. Thus, it is important to develop an efficient stable catalyst able to operate at low temperatures in the aqueous phase. In this sense, carbon materials have particular characteristics that make them stable in polar solvents (e.g., water).

Hydrophilic carbon materials are more relevant for aqueous-phase reactions due to their water compatibility. In this context, we focused herein on the synthesis of highly hydrophilic mesoporous carbon-supported ruthenium $(\mathrm{Ru})$ nanoparticles. This catalyst showed superior performance in the catalytic HDO of a microalgae oil into alkanes (100\% yield) at low temperatures $\left(140{ }^{\circ} \mathrm{C}\right)$ in water. More importantly, the surface of the synthesized carbon material was rich in $-\mathrm{OH}$ groups. These groups increased the hydrophilicity of the carbon material as revealed by the contact angle experiments, which facilitated the good dispersion in water and better contact with the substrates. Kinetics modelling and in situ IR monitoring of the stearic acid HDO in water further revealed superior performance of $\mathrm{Ru} / \mathrm{C}\left(\mathrm{ZnCl}_{2}\right.$, starch) in the tandem hydrogenation of stearic acid and decarbonylation of stearyl alcohol reactions.

\section{Experimental}

\subsection{Chemicals}

All chemicals obtained from commercial suppliers were used as received: glucose (99\%, Sigma-Aldrich), starch (Weifang fengzheng flour Co.), saw dust (Shenzhen kanuo pet Co.), alpha cellulose (Aladdin Industrial Co), melamine (99\%, Sinopharm), activated carbon (Sigma-Aldrich), $\mathrm{RuCl}_{3} \cdot 3 \mathrm{H}_{2} \mathrm{O}$ (99.9\%, Amethyst), $\mathrm{PdCl}_{2}$ (J\&K, >59.5 wt\%), $\mathrm{PtCl}_{4} \quad$ (J\&K, $\geq 58$ wt\%), $\mathrm{ZnCl}_{2}$ (98\%, Sinopharm), $\mathrm{Cu}\left(\mathrm{CH}_{3} \mathrm{COO}\right)_{2} \cdot \mathrm{H}_{2} \mathrm{O}$ (98\%, Sinopharm), $\mathrm{Co}\left(\mathrm{NO}_{3}\right)_{2} \cdot 6 \mathrm{H}_{2} \mathrm{O}$ (99\%, Aladdin Industrial $\left.\mathrm{Co}\right)$, $\mathrm{Ni}\left(\mathrm{NO}_{3}\right)_{2} \cdot 6 \mathrm{H}_{2} \mathrm{O}$ ( $\geq 98 \%$, Sinopharm), $\mathrm{SiO}_{2}$ (Shanghai maikun), microalgae oil was received by Verfahrenstechnik Schwedt $\mathrm{GmbH}$, stearic acid (Sinopharm), HCl (>36\%, Sinopharm), sulphuric acid (98\%, Shanghai Richjoint), diethyl ether anhydrous (Sinopharm, AR), HUSY $\left(\mathrm{SiO}_{2}: \mathrm{Al}_{2} \mathrm{O}_{3}=5\right.$, The Catalyst Plant of Nankai University), Nitrogen, hydrogen gases and air (99.999 vol. \%) were supplied by Shanghai Pujiang Specialty Gases Co., Ltd.

\subsubsection{Synthesis of mesoporous carbon support from starch}

In a typical procedure, the mesoporous carbon support was prepared using starch and zinc chloride. The weight ratio of starch to zinc chloride was kept as (1:2). The mixture of these substances were ground in agate mortar to about 1 hour to mix well and transferred to the ceramic boat for calcinations. The calcination was carried out in $\mathrm{N}_{2}$ flow at $3.3^{\circ} \mathrm{C} \mathrm{min}-1$ at $800{ }^{\circ} \mathrm{C}$ and kept for $1 \mathrm{~h}$. The calcinations furnace was naturally cooled to the room temperature and the sample was crushed into powder form in agate mortar. The sample was treated with $3 \mathrm{M}$ $\mathrm{HCl}$ to remove the zinc chloride thoroughly. The sample was filtered and washed several times using DI water as far as $\mathrm{Cl}^{-}$ ion could not be detected in supernatant. Finally, the mesoporous carbon was dried in an oven at $60^{\circ} \mathrm{C}$ and kept for $20 \mathrm{~h}$.

\subsubsection{Synthesis of $\mathrm{Ru} / \mathrm{C}\left(\mathrm{ZnCl}_{2}\right.$ starch) via wet impregnation method}

The nanoparticles such as $\mathrm{Ru}$ were introduced into the mesoporous carbon support via wet impregnation method. Nanoparticles were loaded in Ru (5 wt\%) by wet impregnation method. After impregnation the sample was dried well in oven. Finally, the sample was reduced under $\mathrm{H}_{2}$ flow at $350^{\circ} \mathrm{C}$ for $4 \mathrm{~h}$ (flowing rate $=100 \mathrm{~mL} \mathrm{~min}^{-1}$, heating rate: $2{ }^{\circ} \mathrm{C} \mathrm{min}-1$ ) and named as $\mathrm{Ru} / \mathrm{C}\left(\mathrm{ZnCl}_{2}\right.$ starch).

\subsubsection{Synthesis of Ru/N-doped carbon support from starch}

The nitrogen doped carbon support was synthesized using starch, melamine and zinc chloride with the weight ratio of (1:1:3). The mixture of these substances were ground in agate mortar to an hour to mix well and transferred to ceramic boat for calcinations. The calcination was performed in nitrogen flow at $3.3^{\circ} \mathrm{C} \mathrm{min}-1$ at $800{ }^{\circ} \mathrm{C}$ for $1 \mathrm{~h}$. The calcinations furnace was naturally cooled to ambient temperature and the sample was crushed into powder form in agate mortar. The sample was treated with $3 \mathrm{M} \mathrm{HCl}$ to remove the zinc chloride thoroughly. The sample was filtered and washed several times using DI water as far as $\mathrm{Cl}^{-}$ion was not detected in supernatant. Finally, the product N-C was dried in an oven at $60^{\circ} \mathrm{C}$ and kept for $20 \mathrm{~h}$. The $\mathrm{Ru}$ nanoparticles (5 wt\%) were loaded into the $\mathrm{N}-\mathrm{C}$ support via wet impregnation method. After impregnation 
the samples were dried well in oven. Finally, the samples were reduced under hydrogen flow at $350{ }^{\circ} \mathrm{C}$ for $4 \mathrm{~h}$ (flowing rate $=$ $100 \mathrm{~mL} \mathrm{~min}^{-1}$, heating rate: $2^{\circ} \mathrm{C} \mathrm{min}^{-1}$ ).

\subsubsection{Synthesis of $\mathrm{Ru} / \mathrm{N}$-doped carbon support from glucose}

In a typical procedure the nitrogen doped carbon support was synthesized using melamine, glucose and zinc chloride. The weight ratio of glucose to melamine was taken as (1:1). The weight ratio of glucose and zinc chloride was kept as (1:3). The mixture of these three substances were ground in agate mortar to one hour to mix well and transferred to ceramic boat for calcinations. The calcination was carried out in nitrogen flow at $3.3{ }^{\circ} \mathrm{C} \mathrm{min}-1$ at $800{ }^{\circ} \mathrm{C}$ for $1 \mathrm{~h}$. The calcinations furnace was naturally cooled to ambient temperature and the sample was crushed into powder form in agate mortar. The sample was treated with $3 \mathrm{M} \mathrm{HCl}$ to remove the zinc chloride. The sample was filtered and washed several times using DI water as far as no $\mathrm{Cl}^{-}$ion was detected in supernatant. Finally, the product $\mathrm{N}-\mathrm{C}$ was dried in an oven at $60{ }^{\circ} \mathrm{C}$ for $20 \mathrm{~h}$. Ru nanoparticles $(5 \%$ wt) were introduced into the $\mathrm{N}-\mathrm{C}$ support via wet impregnation method. After impregnation the samples were dried well in oven. Finally, the samples were reduced under hydrogen flow at $350{ }^{\circ} \mathrm{C}$ for $4 \mathrm{~h}$ (flowing rate $=100 \mathrm{~mL} \mathrm{~min}^{-1}$, heating rate: 2 $\left.{ }^{\circ} \mathrm{C} \min ^{-1}\right)$.

\subsubsection{Synthesis of Ru/C from saw dust and alpha cellulose}

The crushed saw dust/alpha cellulose was washed well using DI water and dried in an oven. Firstly, $4 \mathrm{~g}$ of dried saw dust /alpha cellulose was taken and treated with concentrated sulphuric acid at $60{ }^{\circ} \mathrm{C}$ for two hours until the yellow colour turned into black. Then, the black saw dust/alpha cellulose was thoroughly washed with ultra pure water and dried well. Finally, the product was passed through the wet impregnation method using $\mathrm{Ru}$ (5 wt\% loading) and then reduced the catalyst. The reduction was performed using hydrogen flow at 350 ${ }^{\circ} \mathrm{C}$ for $4 \mathrm{~h}$ (flowing rate $=100 \mathrm{~mL} \mathrm{~min}-1$, heating rate: $2{ }^{\circ} \mathrm{C}$ $\min ^{-1}$ ).

\subsubsection{Synthesis of the Ru catalysts supported on activated car-} bon, $\mathrm{SiO}_{2}$ and $\mathrm{HUSY}$

The nanoparticles $\mathrm{Ru}$ were introduced into other different supports including activated carbon, $\mathrm{SiO}_{2}$ and other metal zeolite such as HUSY via wet impregnation method and then reduced. The samples were reduced using hydrogen flow at $350{ }^{\circ} \mathrm{C}$ for $4 \mathrm{~h}$ (flowing rate $=100 \mathrm{~mL} \mathrm{~min}^{-1}$, heating rate: $2{ }^{\circ} \mathrm{C}$ $\min ^{-1}$ )

\subsection{Catalytic characterization}

Powder X-ray diffraction (XRD) patterns were used to investigate the structure and crystal size by Rigaku Ultima IV X-ray diffractometer utilizing $\mathrm{Cu}-K_{\alpha}$ radiation $(\lambda=1.5405 \AA)$ operated at $35 \mathrm{kV}$ and $25 \mathrm{~mA}$. $\mathrm{N}_{2}$ adsorption measurements were carried out at $77 \mathrm{~K}$ on a BEL-MAX gas/vapor adsorption instrument. The surface areas were measured by the Brunauer-Emmett-Teller (BET) method. The IR spectra of adsorbed butanoic acid (IR-butanoic acid) were recorded with a Nicolet
NEXUS 670 FTIR spectrometer equipped with an in-situ IR cell. Scanning electron microscopy images (SEM) were taken by the Hitachi S-4800 microscope. To illuminate crystal morphology and size, transmission electron microscopy (TEM) images were obtained by the FEI Tecnai G2 F30 microscope working at 300 $\mathrm{kV}$. The calcined samples were characterized using temperature-programmed reduction by a TP-5080 adsorption instrument (equipped with a TCD detector). The gas product was a mixed gas of $5 \% \mathrm{H}_{2} / \mathrm{He}$, and the heating rate was $5{ }^{\circ} \mathrm{C} \mathrm{min}^{-1}$. The Raman spectra were collected on a Raman spectrometer of (JY, HR 800) applying a 514-nm laser. X-ray photoelectron spectroscopy (XPS) were performed with $\mathrm{Al} K \alpha(h v=1486.6$ $\mathrm{eV}$ ) radiation on a Thermo Scientific K-Alpha spectrometer. Charging effects were corrected by using the $\mathrm{C} 1 \mathrm{~s}$ peak owing to adventitious carbon with EB fixed at $284.6 \mathrm{eV}$.

\subsection{Catalytic tests}

In a typical hydrodeoxygenation process, $0.1 \mathrm{~g}$ catalyst ( $\mathrm{Ru} / \mathrm{C}\left(\mathrm{ZnCl}_{2}\right.$ starch), $0.2 \mathrm{~g}$ stearic acid (or $0.2 \mathrm{~g}$ oils) and $80 \mathrm{ml}$ DI water were placed into micro reactor. The autoclave was purged with $\mathrm{N}_{2}$ three times to remove the residual air and then introduced reaction gas ( $5 \mathrm{MPa} \mathrm{H}_{2}$ ) at ambient temperature. The reaction was performed in the micro reactor at $140{ }^{\circ} \mathrm{C}$ and kept for $6 \mathrm{~h}$ with the stirring speed of $500 \mathrm{rpm}$. The autoclave was cooled to ambient temperature naturally. After the reaction, diethyl ether was added to the aqueous solvent to extract the products and substrate, and then analyzed by GC-FID and the products were identified by GC-MS.

\subsection{Test of the algae oil components}

Microalgae oil (5.0 g), methanol (100 mL), and $\mathrm{CaO}(0.8 \mathrm{~g})$ were added into a micro reactor. The reactor was then flushed with nitrogen at ambient temperature for three times. After removal of $\mathrm{N}_{2}$, it was heated up to $80^{\circ} \mathrm{C}$. The reaction was carried out for $2 \mathrm{~h}$ at a stirring speed of $600 \mathrm{rpm}$. After cooling down to room temperature, the liquid products were analyzed by GC coupled with GC-MS.

\section{Result and discussion}

\subsection{Characterization of the physical and chemical properties of the $\mathrm{Ru} /$ mesoporous carbon catalyst}

A catalyst with a Ru loading of $5 \mathrm{wt} \%$ on a mesoporous carbon support was prepared by a wet impregnation method $(\mathrm{Ru} / \mathrm{C})$. The mesoporous carbon support was synthesized using starch (i.e., highly organized mixture of two carbohydrate polymers namely, amylose and amylopectin) as a carbon source and zinc chloride $\left(\mathrm{ZnCl}_{2}\right)$ as an activating Lewis acid and dehydrating agent (Figure S1). The physico-chemical properties of the $\mathrm{Ru}$ /mesoporous carbon $\left(\mathrm{ZnCl}_{2}\right.$ starch) were subsequently compared to those of a $\mathrm{Ru}$ /commercial activated carbon (AC). The powder X-ray diffraction (XRD) pattern of the Ru/AC catalyst (Figure 1a) revealed diffraction peaks at $38.4^{\circ}, 43.5^{\circ}, 69^{\circ}$, and $77^{\circ}$ corresponding to the planes of a hexagonal 
a.

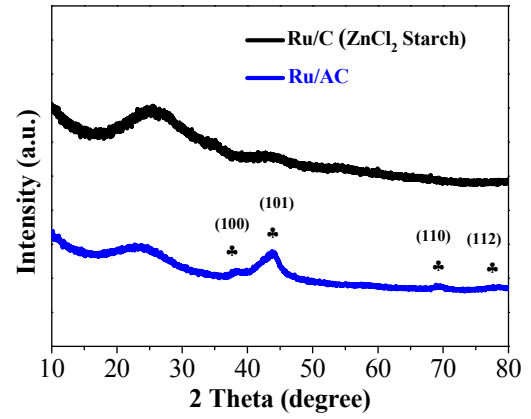

C.

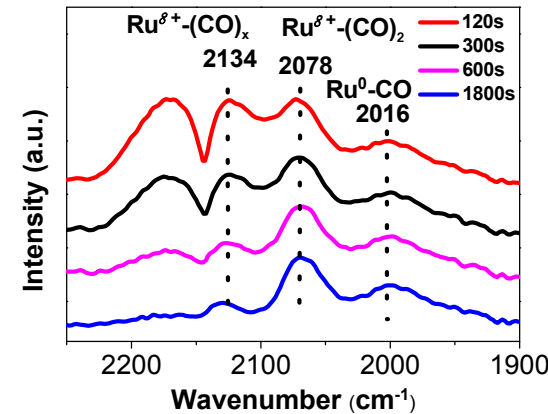

e.

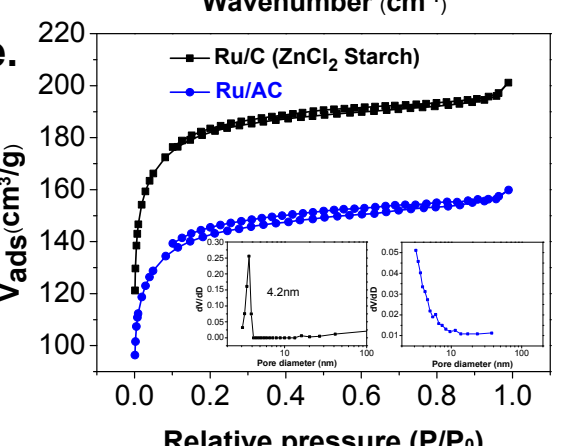

g.



b.

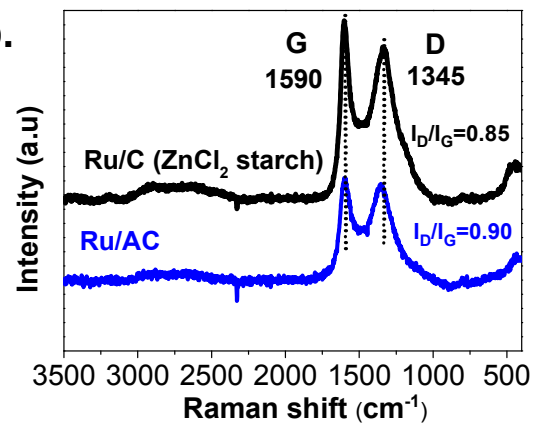

d.



f.

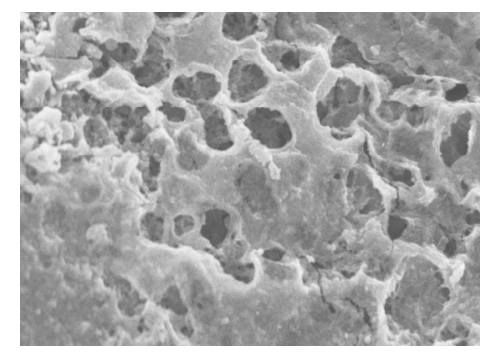

h.
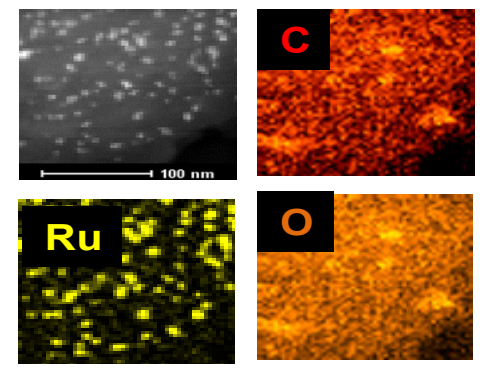

Fig. 1. (a) XRD patterns, (b) Raman spectra, FTIR spectra of adsorbed CO on the surface of (c) $\mathrm{Ru} / \mathrm{C}\left(\mathrm{ZnCl}_{2}\right.$ starch), (d) $\mathrm{Ru} / \mathrm{AC}$ catalysts at room temperature in $\mathrm{CO}$ at $50 \mathrm{~mL} \mathrm{~min}^{-1}$ flow rate, (e) $\mathrm{N}_{2}$ adsorption and desorption isotherms (inset shows the pore size distribution), (f) SEM, (g) TEM, and (h elemental mapping of $\mathrm{C}$, $\mathrm{Ru}$ and $\mathrm{O}$ for $\mathrm{Ru} / \mathrm{C}\left(\mathrm{ZnCl}_{2}\right.$ starch).

close-packed (hcp)-structure of Ru (100), (101), (110), and (112), respectively. In contrast, $\mathrm{Ru} / \mathrm{C}\left(\mathrm{ZnCl}_{2}\right.$ starch) showed no $\mathrm{Ru}$ characteristic peaks, suggesting a good dispersion of $\mathrm{Ru}$ nanoparticles and low particle size. The diffraction peaks at $44^{\circ}$ and ca. $23^{\circ}$ can be ascribed to the (100) planes of graphene and the (002) planes of a pseudo-graphitic phase, respectively [30]. The Raman spectroscopy results are shown in Fig. 1b. The D band $\left(1345 \mathrm{~cm}^{-1}\right)$ and the $\mathrm{G}$ band $\left(1590 \mathrm{~cm}^{-1}\right)$ corresponded to disordered and graphitic carbon, respectively. The intensity ratio of the $\mathrm{D}$ and $\mathrm{G}$ peaks $\left(I_{\mathrm{D}} / I_{\mathrm{G}}\right)$ provided information about structural defects [31]. The $I_{\mathrm{D}} / I_{\mathrm{G}}$ ratio of $\mathrm{Ru} / \mathrm{C}\left(\mathrm{ZnCl}_{2}\right.$ starch) was lower (0.85) than that of Ru/AC (0.90), suggesting the ex- istence of a lower number of structural defects and more graphitic carbons in $\mathrm{Ru} / \mathrm{C}\left(\mathrm{ZnCl}_{2}\right.$ starch).

To provide additional evidence of the surface composition, the Fourier transformed infrared spectroscopy (FTIR) spectra of the catalysts were obtained after adsorption of carbon monoxide (CO) (Figures 1c and 1d). The infrared (IR) spectrum was deconvoluted into three peaks namely, a low intensity peak at $2134 \mathrm{~cm}^{-1}$, a very intense peak at $2078 \mathrm{~cm}^{-1}$, and an unsymmetrical broad peak at $2016 \mathrm{~cm}^{-1}$ which corresponded to $\mathrm{Ru}^{\delta+}-(\mathrm{CO})_{x}, \mathrm{Ru}^{\delta+}-(\mathrm{CO})_{2}$, and $\mathrm{Ru}^{0}-\mathrm{CO}$ adsorption bands, respectively [32,33]. The spectra were recorded for 120, 300, 600, and $1800 \mathrm{~s}$. $\mathrm{Ru} / \mathrm{C}\left(\mathrm{ZnCl}_{2}\right.$ starch) displayed three peaks after 
$1800 \mathrm{~s}$ at 2134, 2078, and $2016 \mathrm{~cm}^{-1}$, and the peak at 2078 $\mathrm{cm}^{-1}$ was significantly broader and more intense than that of the $\mathrm{Ru} / \mathrm{AC}$ catalyst, demonstrating the existence of different $\mathrm{Ru}$ nanoparticles.

Nitrogen sorption was performed to examine the surface area and porosity of the catalysts. The isotherms (Figure 1e) and textural properties of the respective catalysts are shown in Table S1. The specific surface area of the $\mathrm{Ru} / \mathrm{C}\left(\mathrm{ZnCl}_{2}\right.$ starch) catalyst calculated by the Brunauer-Emmet-Teller (BET) method was $S_{\mathrm{BET}}=1550 \mathrm{~m}^{2} \mathrm{~g}^{-1}$, whereas the pore volume and pore size were measured to be $0.5812 \mathrm{~cm}^{3} \mathrm{~g}^{-1}$ and $5.15 \mathrm{~nm}$, respectively. $\mathrm{Ru} / \mathrm{AC}$ showed a specific surface area, pore volume, and pore size of $S_{\text {BET }}$ of $830 \mathrm{~m}^{2} \mathrm{~g}^{-1}, 0.2484 \mathrm{~cm}^{3} \mathrm{~g}^{-1}$, and $3.68 \mathrm{~nm}$, respectively. Thus, the $\mathrm{Ru} / \mathrm{C}\left(\mathrm{ZnCl}_{2}\right.$ starch) catalyst possessed a higher surface area, pore volume, and pore size compared to the $\mathrm{Ru} / \mathrm{AC}$ catalyst. The pore size distribution revealed the existence of mesoporosity in the $\mathrm{Ru} / \mathrm{C}\left(\mathrm{ZnCl}_{2}\right.$ starch) catalyst. Thereby, the high surface area, large pore volume, and high pore size (mesoporosity) of $\mathrm{Ru} / \mathrm{C}$ was beneficial for the adsorption of fatty acids [34].

Scanning electron microscopy (SEM) images of the catalysts revealed different morphologies (Figure 1f). $\mathrm{Ru} / \mathrm{C}\left(\mathrm{ZnCl}_{2}\right.$, starch) had a porous morphology. In contrast, large carbon particles were observed in the SEM images of the Ru/AC cata- lyst (see Figure S5). The dispersion and size of the Ru particles were investigated by transmission electron microscopy (TEM, Figures $1 \mathrm{~h}$ and S6). The images revealed that the nanoparticles of $\mathrm{Ru}$ on the carbon $\left(\mathrm{ZnCl}_{2}\right.$ starch) were well distributed (Figure $1 \mathrm{~g})$ and showed a relatively low size $(3.6 \pm 0.1 \mathrm{~nm}) \mathrm{com}$ pared to those of $\mathrm{Ru} / \mathrm{AC}(4.3 \pm 0.4 \mathrm{~nm}$, Fig. S6). TEM mapping revealed a good distribution of $\mathrm{C}, \mathrm{Ru}$, and $\mathrm{O}$ on the surface of the $\mathrm{Ru} / \mathrm{C}\left(\mathrm{ZnCl}_{2}\right.$ starch) catalyst (Figures $1 \mathrm{~h}$ and $\mathrm{S} 7$ ).

\subsection{Characterization of the surface hydroxyl groups of $R u / C$}

The FTIR spectra for the catalysts (Figure 2a) revealed three main peaks for hydroxyl $(-\mathrm{OH})$ stretching, $\mathrm{C}=\mathrm{C}$, and $-\mathrm{OH}$ out-of-plane bending at 3400, 1530, and $1092 \mathrm{~cm}^{-1}$, respectively. Both catalysts displayed peaks at 3400 and $1530 \mathrm{~cm}^{-1}$ corresponding to $-\mathrm{OH}$ stretching and $\mathrm{C}=\mathrm{C}$ bonds, respectively. Interestingly, the $\mathrm{Ru} / \mathrm{C}\left(\mathrm{ZnCl}_{2}\right.$, starch) catalyst showed an intense and broad peak at $1092 \mathrm{~cm}^{-1}$, confirming the existence of hydroxyl group (i.e., $\mathrm{OH}$ out of plane bands). But this peak was not found in $\mathrm{Ru} / \mathrm{AC}$.

Thermogravimetric analysis (TGA) of the catalysts revealed three peaks at temperatures lower than $100{ }^{\circ} \mathrm{C}$, within $120-579{ }^{\circ} \mathrm{C}$, and at $580{ }^{\circ} \mathrm{C}$ corresponding to the dehydration (removal of moist), removal of oxygenated groups, and de- a.



c.

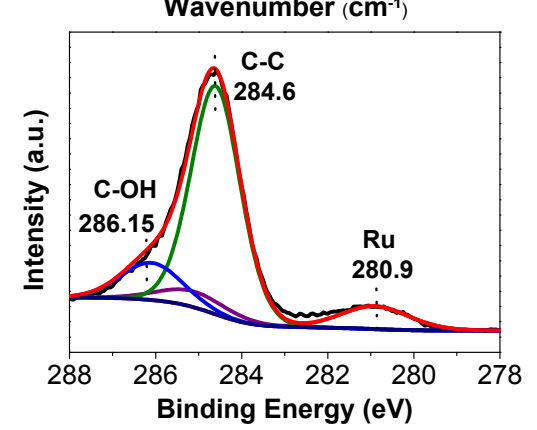

e.

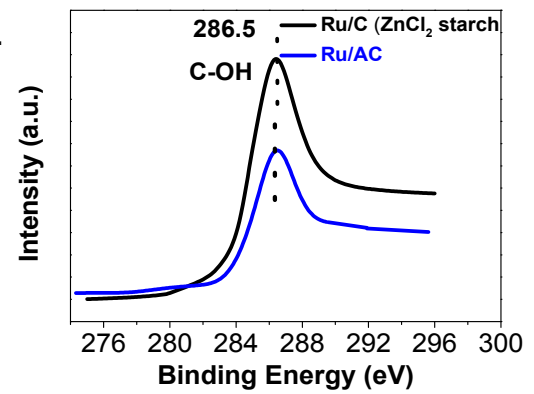

b.

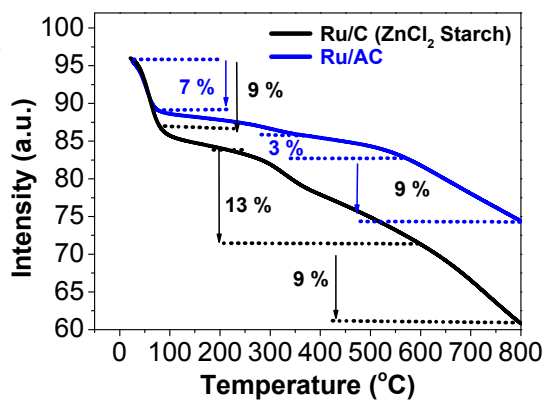

d.

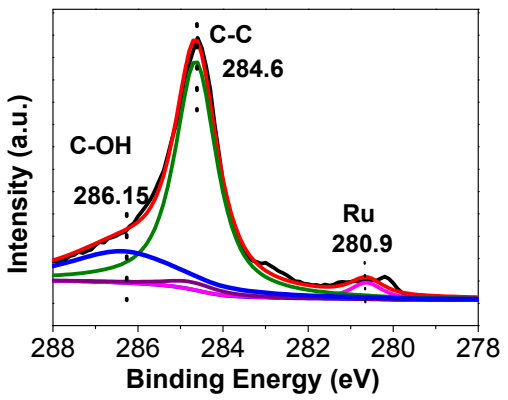

f.



Fig. 2. (a) In situ FTIR spectra, (b) TGA curves, XPS spectra of (c) $\mathrm{Ru} / \mathrm{C}\left(\mathrm{ZnCl}_{2}\right.$ starch), (d) $\mathrm{Ru} / \mathrm{AC}$, (e) comparison of $\mathrm{C}-\mathrm{O}$ peaks and (f) dispersion of $\mathrm{Ru} / \mathrm{C}\left(\mathrm{ZnCl}_{2}\right.$ starch) and $\mathrm{Ru} / \mathrm{AC}$ catalysts in aqueous and ether phases. The bottom layer corresponds to the hydrophilic water and the upper was hydrophobic ether layer (extractor) after the hydrogenation-decarbonylation of fatty acid. 
composition of support, respectively (Figure $2 \mathrm{~b}) . \mathrm{Ru} / \mathrm{C}\left(\mathrm{ZnCl}_{2}\right.$ starch) showed four times weight loss (13\%) than Ru/AC (3\%), in line with FTIR measurements indicating a higher amount of $-\mathrm{OH}$ groups on $\mathrm{Ru} / \mathrm{C}\left(\mathrm{ZnCl}_{2}\right.$ starch).

The X-ray photoelectron spectroscopy (XPS) spectra of $\mathrm{Ru} / \mathrm{C}\left(\mathrm{ZnCl}_{2}\right.$ starch) and $\mathrm{Ru} / \mathrm{AC}$ showed a peak at $284.6 \mathrm{eV}$ (Figures 2c and 2d) corresponding to the graphitic carbon [35]. The peak at $286.5 \mathrm{eV}$ can be attributed to an $s p^{2}$ carbon bonded to a heteroatom, which suggested the presence of $\mathrm{C}-\mathrm{OH}$ groups on the catalysts [36]. Importantly, the peaks of these $\mathrm{C}-\mathrm{OH}$ bonds showed different intensities for the two catalysts, as shown at Figure 2e. It was noted that, the peak of $\mathrm{Ru} / \mathrm{C}\left(\mathrm{ZnCl}_{2}\right.$ starch) at $286.5 \mathrm{eV}$ was more intense than that of $\mathrm{Ru} / \mathrm{AC}$, suggesting the presence of a higher number of $\mathrm{C}-\mathrm{OH}$ bonds compared to $\mathrm{Ru} / \mathrm{AC}$, in line with the above mentioned TGA and FTIR results. It should be noted that the $\mathrm{Ru} / \mathrm{C}\left(\mathrm{ZnCl}_{2}\right.$ starch) catalyst was well dispersed in the aqueous phase, whereas $\mathrm{Ru} / \mathrm{AC}$ was preferably found in the non-aqueous phase (ether phase) after reaction (Figure $2 \mathrm{f}$ ). These data showed that $\mathrm{Ru} / \mathrm{C}$ was highly hydrophilic as a result of its hydroxyl contents on the surface, and thus can be easily dispersed in water. Thereby, contact between the catalyst and the substrate was facilitated on $\mathrm{Ru} / \mathrm{C}\left(\mathrm{ZnCl}_{2}\right.$ starch) in the water, leading to good performance towards the hydrodeoxygenation of stearic acid.

Contact angle tests are quite important to address the wetting properties of different supports with the polar and non-polar solvents $[37,38]$. Based on contact angle tests with water on $\mathrm{Ru} / \mathrm{C}\left(\mathrm{ZnCl}_{2}\right.$ starch) $\left(21.32^{\circ}\right)$ and $\mathrm{Ru} / \mathrm{AC}\left(23.78^{\circ}\right)$ (see Figure 3), it can be speculated that $\mathrm{Ru} / \mathrm{C}\left(\mathrm{ZnCl}_{2}\right.$ starch) is more hydrophilic than $\mathrm{Ru} / \mathrm{AC}$ by comparing the different interaction angles with water. The higher hydrophilic property on $\mathrm{Ru} / \mathrm{C}$ $\left(\mathrm{ZnCl}_{2}\right.$ starch) may be derived from the abundant surface $-\mathrm{OH}$ groups as discussed in the former part (Figure 2). In comparison, the contact angle tests with non-polar solvents of cyclohexane and diethyl ether consistently demonstrated $\mathrm{Ru} / \mathrm{C}$ $\left(\mathrm{ZnCl}_{2}\right.$ starch) showed smaller contact angles compared to $\mathrm{Ru} / \mathrm{AC}$ (Figure 3), probably due to the more abundant graphitic

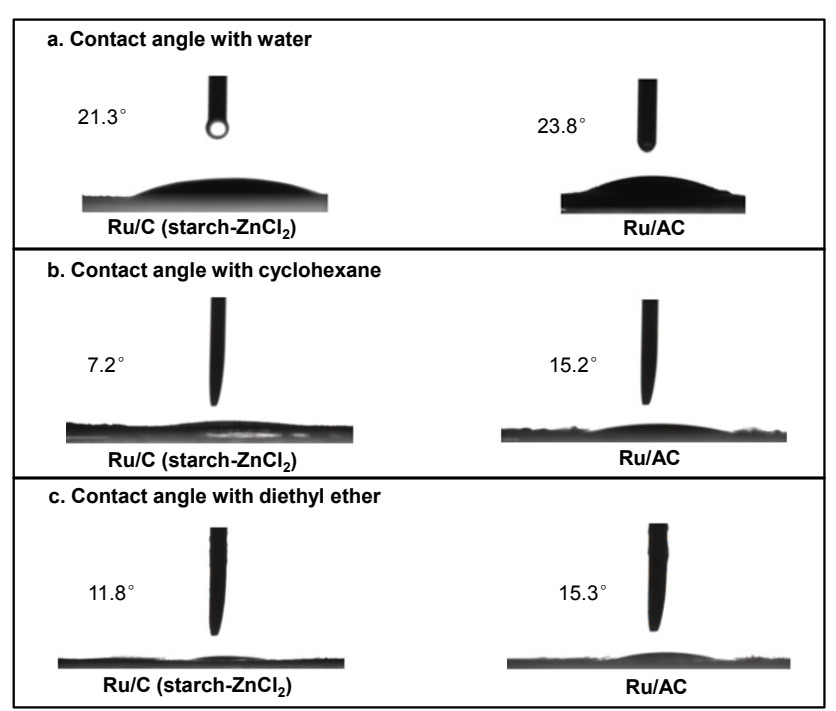

Fig. 3. Contact angle tests with (a) water, (b) cyclohexane, and (c) diethyl ether on $\mathrm{Ru} / \mathrm{C}\left(\mathrm{ZnCl}_{2}\right.$ starch) and $\mathrm{Ru} / \mathrm{AC}$ samples. structures in the carbon material as indicated by the peak at $1590 \mathrm{~cm}^{-1}$ of Raman spectra in Figure $1 \mathrm{~b}$.

\subsection{Screening of supported Ru catalysts for the hydrodeoxygenation of fatty acids in water}

To evaluate the activity of the different materials, several catalysts with similar Ru loadings (5 wt\%) were synthesized (Figures S1-S4) on a range of supports derived from starch, glucose, AC, alpha cellulose, and sawdust as well as silicon dioxide $\left(\mathrm{SiO}_{2}\right)$ and HUSY. The catalytic results are shown in Table 1. Among the catalysts evaluated, $\mathrm{Ru} / \mathrm{C}\left(\mathrm{ZnCl}_{2}\right.$ starch) displayed the best performance $(100 \%$ conversion of stearic acid: $88 \%$ yield to heptadecane and $12 \%$ to octadecane). Interestingly, $\mathrm{Ru} / \mathrm{C}$ (starch) showed a 78\% yield to heptadecane and an $8 \%$ yield to octadecane under identical conditions. Thus, the activation of carbon with $\mathrm{ZnCl}_{2}$ played an important role in enhancing the yield of heptadecane. $\mathrm{ZnCl}_{2}$ can be preferably used as activating agents to produce pores in carbon materials $[39,45]$ due to their facile removal after calcinations via acid etching process over $\mathrm{AlCl}_{3}$ and $\mathrm{FeCl}_{3}[46,47]$. Likewise, $\mathrm{AlCl}_{3}$ and $\mathrm{FeCl}_{3}$ can be intercalated between graphitic layers of carbon materials, increasing the interlaminar spacing and producing strong acid catalysts [47] which might affect the activity of the catalysts. The catalysts supported on AC and glucose showed good conversions to high stearic alcohol $(52 \%$ and $44 \%$ ) and low heptadecane ( $43 \%$ and $6 \%$ ) yields, respectively. In contrast, catalysts supported on saw dust and alpha cellulose showed the lowest conversion $(26 \%$ and $47 \%)$ and stearic alcohol $(3 \%$ and $7 \%)$ and heptadecane $(1 \%$ and $3 \%)$ yields, respectively. Starch and glucose nitrogen-doped carbon (N-C) supports also showed good conversion and high stearic alcohol yields $(70 \%$ and $75 \%)$, although low yields to heptadecane (9.6\% and 5\%) were achieved, respectively. The nitrogen functionalities on the support may favour strong adsorption of stearic acid yielding stearic alcohol [39]. The catalysts supported on HUSY and $\mathrm{SiO}_{2}$ showed good conversions and produced lower heptadecane (73\% and 58\%) and stearic alcohol ( $1 \%$ and $34 \%)$ yields, respectively, compared to $\mathrm{Ru} / \mathrm{C}\left(\mathrm{ZnCl}_{2}\right.$

Table 1

Catalytic performance of different Ru-based catalysts for the stearic acid hydrodeoxygenation reactions.

\begin{tabular}{|c|c|c|c|c|c|c|}
\hline \multirow{2}{*}{$\begin{array}{l}\text { En- } \\
\text { try } \\
\end{array}$} & \multirow{2}{*}{ Catalyst } & \multirow{2}{*}{$\begin{array}{c}\text { Conv. } \\
(\%)\end{array}$} & \multicolumn{4}{|c|}{ Yield (\%) } \\
\hline & & & $n-\mathrm{C}_{17} \mathrm{H}_{36}$ & $\mathrm{C}_{18} \mathrm{H}_{37} \mathrm{O}$ & $n-\mathrm{C}_{18} \mathrm{H}_{38}$ & Ester \\
\hline 1 & $\mathrm{Ru} / \mathrm{N}-\mathrm{C}$ (starch) & 100 & 10 & 70 & 2 & 18 \\
\hline 2 & $\mathrm{Ru} / \mathrm{C}$ calcined (starch) ${ }^{\mathrm{a}}$ & 100 & 78 & 6 & 8 & 8 \\
\hline 3 & $\mathrm{Ru} / \mathrm{C}\left(\mathrm{ZnCl}_{2}\right.$ starch $)$ & 100 & 88 & - & 12 & - \\
\hline 4 & Ru/N-C (glucose) & 100 & 5 & 75 & 10 & 10 \\
\hline 5 & $\mathrm{Ru} /$ activated carbon $(\mathrm{AC})$ & 100 & 43 & 52 & 2 & 3 \\
\hline 6 & $\mathrm{Ru} / \mathrm{C}$ (glucose) & 92 & 6 & 44 & 4 & 38 \\
\hline 7 & Ru/C (alpha cellulose) & 43 & 3 & 7 & - & 33 \\
\hline 8 & $\mathrm{Ru} / \mathrm{C}$ (saw dust) & 26 & 1 & 3 & - & 22 \\
\hline 9 & $\mathrm{Ru} /$ Silica & 100 & 58 & 34 & 8 & - \\
\hline 10 & $\mathrm{Ru} / \mathrm{HUSY}$ & 100 & 73 & 1 & 8 & 18 \\
\hline
\end{tabular}

Reaction conditions: $0.1 \mathrm{~g}$ catalyst (5wt\% Ru), 0.2 g stearic acid in 80 $\mathrm{mL}$ water at $160{ }^{\circ} \mathrm{C}$ and $5.0 \mathrm{MPa} \mathrm{H}_{2}$ for $6 \mathrm{~h}$. a The calcined carbon support derived from starch without using $\mathrm{ZnCl}_{2}$. 
$100{ }^{\circ} \mathrm{C}$

a.

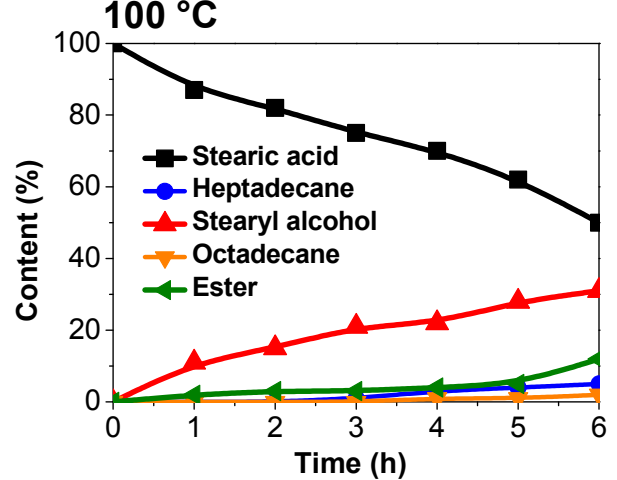

$140{ }^{\circ} \mathrm{C}$

c.

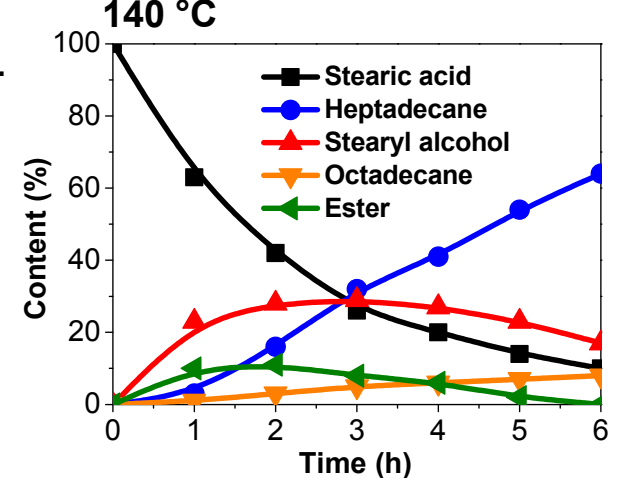

$120^{\circ} \mathrm{C}$

b.

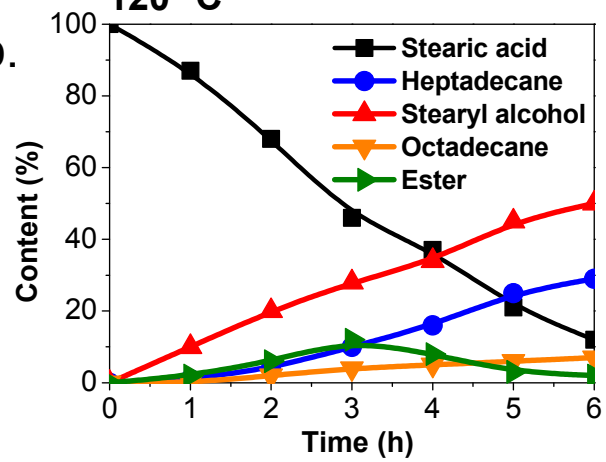

$160^{\circ} \mathrm{C}$

d.

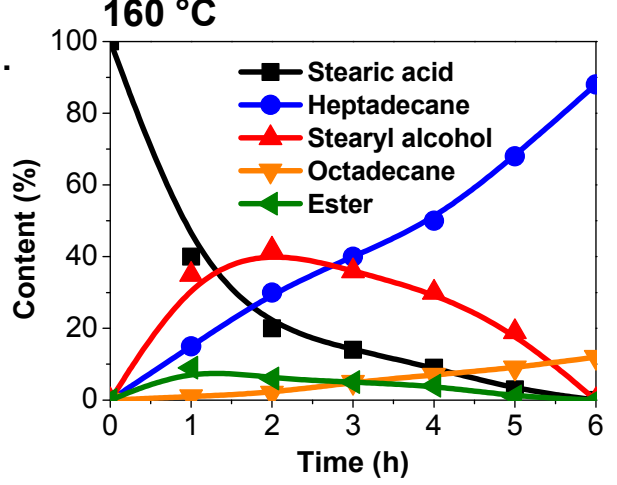

Fig. 4. Stearic acid conversion at different temperatures: (a) $100{ }^{\circ} \mathrm{C}$, (b) $120^{\circ} \mathrm{C}$, (c) $140{ }^{\circ} \mathrm{C}$, and (d) $160{ }^{\circ} \mathrm{C}$. Reaction conditions: $\mathrm{Ru} / \mathrm{C}(\mathrm{ZnCl} 2$ starch) catalyst $(0.1 \mathrm{~g})$, stearic acid $(0.2 \mathrm{~g}), 5.0 \mathrm{MPa}\left(\mathrm{H}_{2}\right)$, and water $(80 \mathrm{~mL})$ with stirring at $500 \mathrm{rpm}$.

starch). Under optimized conditions $\left(140^{\circ} \mathrm{C}, 5.0 \mathrm{MPa} \mathrm{H}_{2}\right), \mathrm{Ru} / \mathrm{C}$ $\left(\mathrm{ZnCl}_{2}\right.$ starch) achieved the heptadecane and octadecane yields of $88 \%$ and $12 \%$, respectively, with $100 \%$ conversion of stearic acid.

The results depicted in the Table S2 showed that Ru was found to be more effective [40] for cascade hydrogenation-decarbonylation reactions compared to $\mathrm{Pd}, \mathrm{Pt}, \mathrm{Co}, \mathrm{Ni}$ and $\mathrm{Cu}$ nanoparticles. The optimum temperature for the hydrogenation-decarbonylation of stearic acid was found to be 160 ${ }^{\circ} \mathrm{C}$ (Figure S8a) over $\mathrm{Ru} / \mathrm{C}\left(\mathrm{ZnCl}_{2}\right.$ starch). As the temperature increased, the stearic alcohol yield decreased in favour of alkane produced via decarbonylation of stearic alcohol. At temperatures up to $120{ }^{\circ} \mathrm{C}$, the stearic alcohol remained as the dominant product (45\%), and above this temperature $\left(140{ }^{\circ} \mathrm{C}\right.$ and $160{ }^{\circ} \mathrm{C}$ ), alkanes remained the dominant product $(72 \%$ and $100 \%$, respectively). It may indicate that, low temperatures favored the hydrogenation of stearic acid while high temperatures facilitated the decarbonylation of stearic alcohol [41-44].

By studying the effects of hydrogen on hydrogenation and decarbonylation reactions at the optimized temperature $(160$ ${ }^{\circ} \mathrm{C}$ ), we found the optimum hydrogen pressure over $\mathrm{Ru} / \mathrm{C}$ $\left(\mathrm{ZnCl}_{2}\right.$ starch) to be 5.0 MPa (Figure S8b). The alkane yield over $\mathrm{Ru} / \mathrm{C}\left(\mathrm{ZnCl}_{2}\right.$ starch) increased with time to reach $100 \%$ (88\% heptadecane, $12 \%$ octadecane yield; $6 \mathrm{~h}$, Figure $4 \mathrm{~d}$ ). On the other hand, the alkane and stearic alcohol yields increased with time over the $\mathrm{Ru} / \mathrm{AC}$ catalyst up to $6 \mathrm{~h}$, resulting in $100 \%$ conversion (43\% heptadecane, 52\% stearic alcohol, 2\% heptadecane, and 3\% ester, Figure S9). The kinetic data at different temperatures $\left(120-160^{\circ} \mathrm{C}\right)$ up to the optimized time of $6 \mathrm{~h}$ over $\mathrm{Ru} / \mathrm{C}\left(\mathrm{ZnCl}_{2}\right.$ starch) are shown in Figure 4.

\subsection{Aqueous-phase stearic acid hydrogenation and decarbonylation: a kinetic study}

Based on the observations and analyses of the main products obtained by HDO of stearic acid over $\mathrm{Ru} / \mathrm{C}\left(\mathrm{ZnCl}_{2}\right.$ starch) at different temperatures (Figure 4), we proposed herein a reaction network (see Scheme S1). The major route contained two main steps, namely, hydrogenation of stearic acid to stearyl alcohol and decarbonylation/hydrogenation of stearyl alcohol to heptadecane. In addition, stearic alcohol can be also transformed to the corresponding ester (minor product at low temperatures). Meanwhile, stearic alcohol can be dehydrated to octadecene (not detected due to fast sequential hydrogenation steps) and then converted into octadecane which is also a minor route. The reaction network further demonstrated that hydrogenation is the primary and fastest step, forming stearic alcohol $\left(k_{1}\right)$; afterwards, stearic alcohol is decarbonylated to the target product heptadecane $\left(k_{2}\right)$ with a relatively low rate.

The concentration of hydrogen before and after was assumed to be unchanged (zero order). Guided by the information from the reaction network (Scheme S1), the major reaction route and the reaction equations are shown in Figures $5 \mathrm{a}$ and $5 \mathrm{~b}$. The fitting curves for the individual steps of stearic acid hydrogenation and decarbonylation (measured by MATLAB software) are plotted in Figures S10 and S11, whereas the individual fitted values are compiled in Table 2 .

The fitted data for stearic acid hydrogenation and decar- 
Table 2

Calculation results of rate constants for the individual steps of $k_{1}$ (stearic acid hydrogenation) and $k_{2}$ (stearic alcohol decarbonylation) reactions over $\mathrm{Ru} / \mathrm{C}\left(\mathrm{ZnCl}_{2}\right.$ starch) and $\mathrm{Ru} / \mathrm{AC}$ catalysts.

\begin{tabular}{lccc}
\hline Catalyst & $T\left({ }^{\circ} \mathrm{C}\right)$ & $k_{1}\left(\mathrm{~min}^{-1}\right)$ & $k_{2}\left(\mathrm{~min}^{-1}\right)$ \\
\hline $\mathrm{Ru} / \mathrm{C}\left(\mathrm{ZnCl}_{2}\right.$ starch) & 100 & 0.0023 & 0.0015 \\
$\mathrm{Ru} / \mathrm{C}\left(\mathrm{ZnCl}_{2}\right.$ starch) & 120 & 0.0037 & 0.0031 \\
$\mathrm{Ru} / \mathrm{C}\left(\mathrm{ZnCl}_{2}\right.$ starch) & 140 & 0.0054 & 0.0061 \\
$\mathrm{Ru} / \mathrm{C}\left(\mathrm{ZnCl}_{2}\right.$ starch) & 160 & 0.0124 & 0.0074 \\
$\mathrm{Ru} / \mathrm{AC}$ & 160 & 0.0082 & 0.0027 \\
\hline
\end{tabular}

bonylation revealed that the primary steps of hydrogenation were faster $\left(0.0023,0.0037,0.0054\right.$, and $\left.0.0124 \mathrm{~g}^{-1} \mathrm{~min}^{-1}\right)$ than the decarbonylation steps $(0.0015,0.0031,0.0061$, and 0.0074 $\mathrm{g}^{-1} \mathrm{~min}^{-1}$ ) at $100,120,140$, and $160^{\circ} \mathrm{C}$, respectively. Within the $100-160{ }^{\circ} \mathrm{C}$ reaction temperature range, the hydrogenation rate of $-\mathrm{COOH}\left(k_{1}\right)$ and decarbonylation of $-\mathrm{CH}_{2} \mathrm{OH}\left(k_{2}\right)$ increased with temperature. When the temperature increased from 100 to $160{ }^{\circ} \mathrm{C}, k_{1}$ rapidly increased (5.4-fold) from 0.0023 to $0.0124 \mathrm{~g}^{-1} \mathrm{~min}^{-1}$, while $k_{2}$ gradually increased (4.9-fold) from 0.0015 to $0.0074 \mathrm{~g}^{-1} \mathrm{~min}^{-1}$, further proving a high temperature dependence. The rate constants $k_{1}$ and $k_{2}$ obtained for $\mathrm{Ru} / \mathrm{AC}$ were relatively lower than those shown by $\mathrm{Ru} / \mathrm{C}\left(\mathrm{ZnCl}_{2}\right.$ starch) at $160{ }^{\circ} \mathrm{C}$, confirming that the hydrogenation of stearic acid and the decarbonylation of stearic alcohol were carried out at relatively lower rates over $\mathrm{Ru} / \mathrm{AC}$ catalyst (Figures $\mathrm{S} 9$ and $\mathrm{S} 11)$. The activation energy $\left(E_{\mathrm{a}}\right)$ values calculated for the hy-

a.

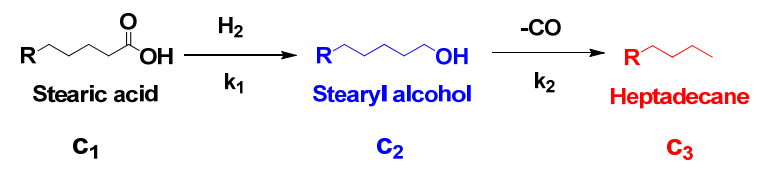

b.

$$
\begin{aligned}
& \mathrm{dc}_{1} / \mathrm{dt}=-k_{1} \times c_{1} \\
& \mathrm{dc}_{2} / \mathrm{dt}=k_{1} \times c_{1}-k_{2} \times c_{2} \\
& \mathrm{dc}_{3} / \mathrm{dt}=k_{2} \times c_{2}
\end{aligned}
$$

Fig. 5. Reaction steps (a) and individual reaction equations (b) for stearic acid hydrogenation-decarbonylation to alkanes in water.

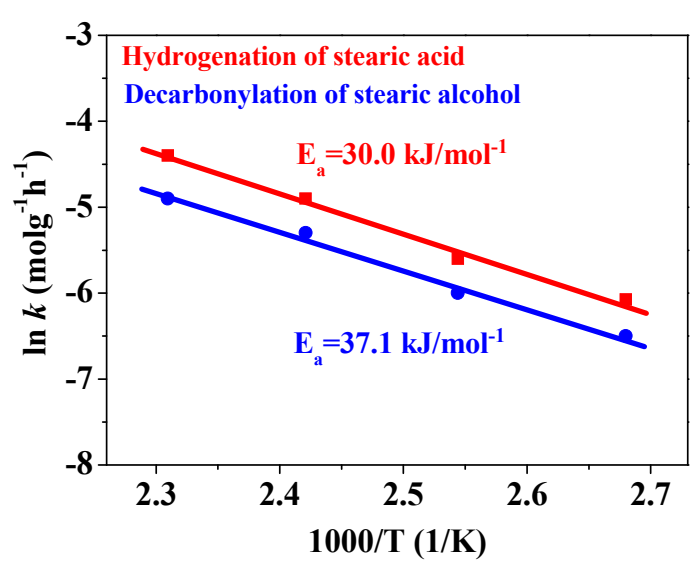

Fig. 6. Arrhenius plots for the hydrogenation of stearic acid and decarbonylation of stearyl alcohol over $\mathrm{Ru} / \mathrm{C}\left(\mathrm{ZnCl}_{2}\right.$, starch) at temperatures of $100,120,140$, and $160^{\circ} \mathrm{C}$. drogenation of stearic acid and the decarbonylation of stearic alcohols were 30.0 and $37.1 \mathrm{~kJ} \mathrm{~mol}^{-1}$ over $\mathrm{Ru} / \mathrm{C}\left(\mathrm{ZnCl}_{2}\right.$, starch), respectively (Figure 6). The main liquid and gaseous products detected by gas chromatography coupled with mass spectroscopy (GC-MS) after aqueous phase transformation of stearic acid are depicted in Figures S12 and S13, respectively. Likewise, GC revealed the presence of $\mathrm{CH}_{4}$ and no $\mathrm{CO}$, which confirmed that $\mathrm{CO}$ reacted with $\mathrm{H}_{2}$ to form methane via methanation in the gas phase (Figure S13)

\subsection{In situ IR measurements of $\mathrm{C}_{4}$ acid hydrodeoxygenation in} water

In a subsequent step, we conducted in situ FTIR to investigate the adsorption and hydrodeoxygenation of butyric acid (as a representative of stearic acid) on the two $\mathrm{Ru} / \mathrm{C}$ catalysts. The experimental data (Figure 7a) revealed a peak at $1720 \mathrm{~cm}^{-1}$

a.

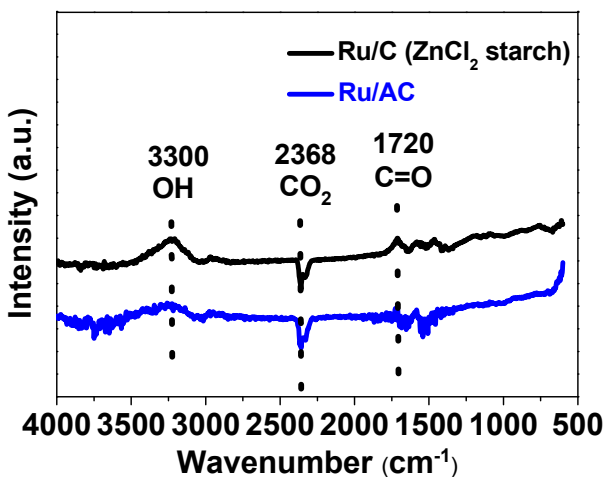

b.



C.

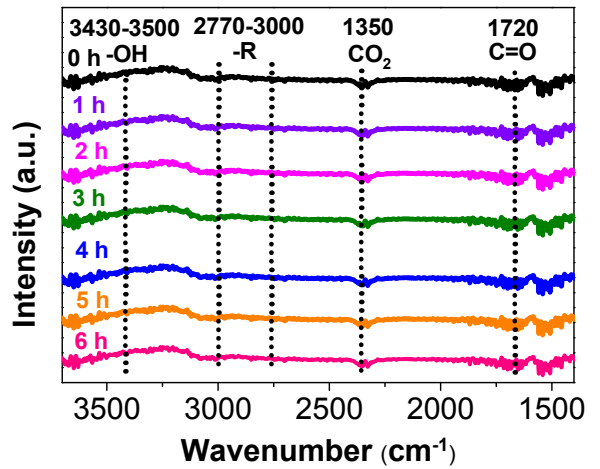

Fig. 7. In situ FTIR for (a) butyric acid adsorption in He at room temperature. In situ FTIR for hydrogenation-decarbonylation over (b) Ru/C $\left(\mathrm{ZnCl}_{2}\right.$ starch) and (c) $\mathrm{Ru} / \mathrm{AC}$ (activated carbon) catalysts in $\mathrm{H}_{2}$ at 160 ${ }^{\circ} \mathrm{C}(1-6 \mathrm{~h})$ with a flow rate of $50 \mathrm{~mL} \mathrm{~min}^{-1}$. 

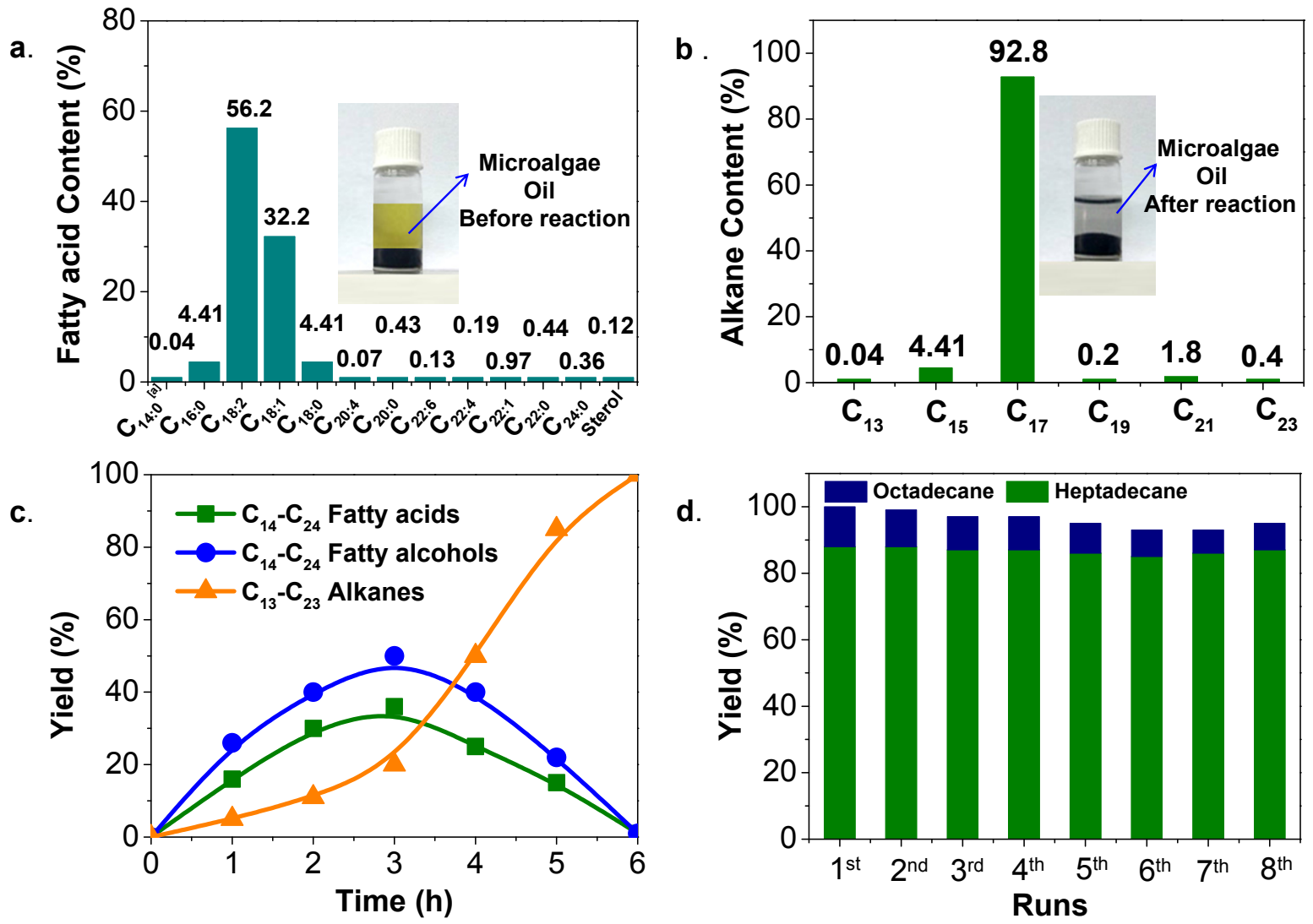

Fig. 8. (a) Fatty acid composition of the microalgae oil used herein and nomenclature represents the number of carbon atoms and the number of $\mathrm{C}=\mathrm{C}$ double bonds. For instance, the alkyl chain of the present fatty acid contains 14 carbon atoms and no double bond. (b) Distribution of alkane contents from microalgae oil as detected by GC-MS. (c) Product distribution for transformation of microalgae oil over Ru/C $\left(\mathrm{ZnCl}_{2} \mathrm{starch}\right) \mathrm{catalyst}$ at $140{ }^{\circ} \mathrm{C}$. (d) Recycling tests of hydrogenation and decarbonylation of stearic acid over $\mathrm{Ru} / \mathrm{C}\left(\mathrm{ZnCl}_{2}\right.$ starch) catalyst (treated by sequential hydrogen reduction).

produced by the carbonyl group of pure butyric acid. $\mathrm{Ru} / \mathrm{C}$ $\left(\mathrm{ZnCl}_{2}\right.$ starch) displayed an adsorption peak at $1720 \mathrm{~cm}^{-1}$ for butyric acid. In contrast, the Ru/AC catalyst did not display such peak at $1720 \mathrm{~cm}^{-1}$, because of its weak adsorption of butyric acid (see Table S1).

In situ FTIR measurement may reveal the mechanism for the transformation of fatty acids (butanoic acid) into alkanes (propane) in $\mathrm{H}_{2}$ at $160{ }^{\circ} \mathrm{C}$ over $\mathrm{Ru} / \mathrm{C}\left(\mathrm{ZnCl}_{2}\right.$ starch). The experimental data are presented in Figure $7 \mathrm{~b}$. It was observed that no hydrogenation took place after $1 \mathrm{~h}$. But after $2 \mathrm{~h}$, the peak at $1720 \mathrm{~cm}^{-1}$ disappeared and peaks appeared at ca. 2800 and $3300 \mathrm{~cm}^{-1}$ corresponding to alkyl $(-\mathrm{R})$ and alcohol $(-\mathrm{OH})$ groups, respectively, which confirmed the hydrogenation of fatty acids to fatty alcohols [39]. Interestingly, peak at 3430-3500 $\mathrm{cm}^{-1}$ corresponding to the $-\mathrm{OH}$ of alcohol disappeared after $4 \mathrm{~h}$, revealing the complete decarbonylation (-CO) of fatty alcohol to alkanes (final product) via cascade hydrogenation-decarbonylation reactions

In contrast, due to the weak adsorption peaks for the carbonyl group of $\mathrm{Ru} / \mathrm{AC}$, in situ FTIR could not observe the hydrogenation and decarbonylation processes (see Figure 7c).

\subsection{The hydrodeoxygenation HDO of microalgae oil over $\mathrm{Ru} / \mathrm{C}$} in water
The scope of the aqueous-phase hydrogenation-decarbonylation reaction was further extended to the feedstock of microalgae oil. The microalgae oil was completely transformed into alkanes $(99.6 \%$ total alkanes and $92.8 \%$ heptadecane) at a relatively low temperature of $140{ }^{\circ} \mathrm{C}$. After the reaction, the colour of the microalgae oil changed completely. The chemical composition of the algae oil (see Figure 8a) and the chemical composition of the alkane products determined by GC-MS are shown in Figures 8b and S14. Likewise, the distribution of products obtained during the transformation of microalgae oil over $\mathrm{Ru} / \mathrm{C}\left(\mathrm{ZnCl}_{2}\right.$ starch) at $140{ }^{\circ} \mathrm{C}$ are shown in Figure $8 \mathrm{c}$ as a function of time. $\mathrm{C}_{14}-\mathrm{C}_{24}$ fatty acids and fatty alcohols were the main intermediates, and $\mathrm{C}_{13}-\mathrm{C}_{23}$ alkanes were the final target products.

The stability of the $\mathrm{Ru} / \mathrm{C}\left(\mathrm{ZnCl}_{2}\right.$ starch) catalyst was investigated by recycling the catalysts after several stearic acid hydrogenation and decarbonylation experiments. After the reaction, the catalyst was separated and reduced again before using fresh reactants. The catalyst was found to disperse well in water (Figure 2f), and was reactive even after eight consecutive runs, revealing high stability (Figure 8d). After eight cycles, the used $\mathrm{Ru} / \mathrm{C}\left(\mathrm{ZnCl}_{2}\right.$ starch) catalyst was characterized by XRD (Figure S15) and TEM (Figure S16), and slight changes were observed. The recycling tests and characterization measure- 


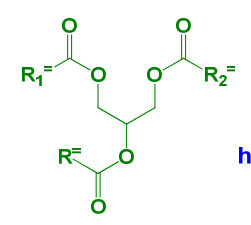

microalgae oil

$\mathrm{R}-\mathrm{COOH} \underset{\text { hydrogenation }}{\stackrel{\mathrm{H}_{2}}{\longrightarrow}} \mathrm{R}-\mathrm{CHO} \underset{\text { hydrogenation }}{\stackrel{\mathrm{H}_{2}}{\longrightarrow}} \mathrm{R}-\mathrm{CH}_{2} \mathrm{OH} \underset{\text { decarbonylation }}{\stackrel{\mathrm{H}_{2}-\mathrm{CO}}{\longrightarrow}} \mathrm{R}-\mathrm{CH}_{3}$

fatty acids aldehyde fatty alcohols alkanes

Fig. 9. Mechanism for the transformation of microalgae oil into alkanes.

ments revealed that the catalyst used was sustainable, recyclable, and environmentally benign.

The mechanism for transformation of microalgae oil into alkanes can be explained in base of hydrogenation, hydrogenolysis, and decarbonylation steps (see Figure 9). First, the microalgae oil undergoes hydrogenation to yield hydrogenated triglyceride, which undergoes further hydrogenolysis to fatty acids. Ru nanoparticles further hydrogenate the fatty acids into fatty alcohols through an intermediate aldehyde in the presence of high-pressurized $\mathrm{H}_{2}$ [32,39]. The high hydrophilicity of the $\mathrm{Ru} / \mathrm{C}\left(\mathrm{ZnCl}_{2}\right.$ starch) catalyst favoured its good dispersion in water, facilitating the fast hydrogenation and decarbonylation steps occurred at the low temperatures in the aqueous phase.

\section{Conclusions}

While the preparation of water-tolerant and hydrothermally stable catalysts is quite important for aqueous-phase reactions, many supports are easily damaged by steaming. Carbon materials are quite stable and have high surface areas. However, they are highly hydrophobic but less hydrophillic, making it difficult to contact the reactants in water. Here, we synthesized highly hydrophilic mesoporous carbon-supported Ru nanoparticles to catalyze quantitative HDO of microalgae oil to alkanes in water at a low temperature of $140{ }^{\circ} \mathrm{C}$.

The mesoporous carbon produced by calcination of starch and $\mathrm{ZnCl}_{2}$ in $\mathrm{N}_{2}$ showed high surface areas and pore volume, which allowed high dispersion of Ru nanoparticles. The surface of the carbon material was rich in - $\mathrm{OH}$ groups, as evidenced by XPS, IR, and TGA measurements. These hydroxyl groups increased the hydrophilicity of the carbon material, which was well dispersed in water and facilitated contact with the substrates. Likewise, contact angle test results speculated the superior hydrophilic nature of mesoporous $\mathrm{Ru} / \mathrm{C}\left(\mathrm{ZnCl}_{2}\right.$, starch) than commercial $\mathrm{Ru} / \mathrm{C}$. In addition, $\mathrm{Ru} / \mathrm{C}$ showed high durability after consecutive runs. The results of this study provide a facile and universal method for preparing efficient hydrogenation catalysts operating at high temperatures in the aqueous phase.

\section{References}

[1] C. Zhao, T. Brück, J. A. Lercher, Green Chem., 2013, 15, 1720-1739.

[2] B. Peng, Y. Yao, C. Zhao, J. A. Lercher, Angew. Chem. Int. Ed., 2012, 51, 2072-2075.

[3] M. Mofijur, M. Rasul, G. Hassan, M. N. Nabi, Energy Procedia, 2019, 156, 53-58.

[4] F. Arcigni, R. Friso, M. Collu, M. Venturini, Renew. Sustain. Energy Rev., 2019, 101, 614-624.

[5] P. Darvehei, P. A. Bahri, N. R. Moheimani, Renew. Sustain. Energy Rev., 2018, 97, 233-258.

[6] Y. Wang, M. Peng, J. Zhang, Z. Zhang, J. An, S. Du, D. Ma, Nat. Commun., 2018, 9, 5183.

[7] A. Chatterjee, S. H. Eliasson, K. W. Törnroos, V. R. Jensen, ACS Catal., 2016, 6, 7784-7789.

[8] L. Di, S. Yao, S. Song, G. Wu, W. Dai, N. Guan, L. Li, Appl. Catal. B, 2017, 201, 137-149.

[9] Z. Luo, Z. Zheng, L. Li, Y. T. Cui, C. Zhao, ACS Catal., 2017, 7, 8304-8213.

[10] A. Ali, C. Zhao, Chin. J. Catal., 2020, 41, 375-389.

[11] G. Zafeiropoulos, N. Nikolopoulos, E. Kordouli, Catalysts, 2019, 9, 9030210.

\section{Graphical Abstract}

Chin. J. Catal., 2020, 41: 1174-1185 doi: 10.1016/S1872-2067(20)63539-2

Ru nanoparticles supported on hydrophilic mesoporous carbon catalyzed low-temperature hydrodeoxygenation of microalgae oil to alkanes at aqueous-phase

Arif Ali, Chen Zhao *

East China Normal University

This work focuses on the synthesis of Ru nanoparticles supported on mesoporous carbon rich in $-\mathrm{OH}$ groups, which makes it to be more hydrophillic. This catalyst delivered the tandem hydrogenation and decarbonylation reactions, producing $100 \%$ yield of diesel-range alkanes at a low temperature of $140{ }^{\circ} \mathrm{C}$ in aqueous phase.

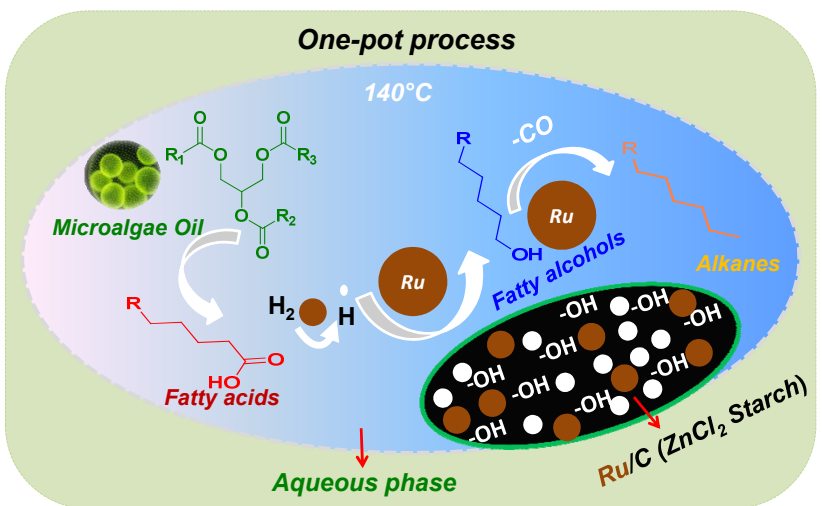


[12] D. Agarwal, A. K. Agarwal, Appl. Therm. Engin., 2007, 27, 2314-2323.

[13] C. Zhao, Y. Kou, A. A. Lemoniduo, X. Li, J. Lercher, Angew. Chem. Int. Ed., 2009, 48, 3987-3990.

[14] M. D. Krcha, K. M. Dooley, M. J. Janik, J. Catal., 2015, 330, 167-176.

[15] B. Ma, X. Yi, L. Chen, A. Zheng, C. Zhao, J. Mater. Chem. A, 2016, 4, 11330-11341.

[16] B. Ma, J. Hu, Y. Wang, C. Zhao, Green Chem., 2015, 17, 4610-4617.17.

[17] J. Zhang, C. Zhao, Chem. Commun., 2015, 51, 17249-17252.

[18] B. Ma, C. Zhao, Green Chem., 2015, 17, 1692-1701.

[19] G. W. Huber, P. O'Connor, A. Corma, Appl. Catal. A, 2007, 329, 120-129.

[20] D. P. Serrano, J. M. Escola, L. Briones, M. Arroyo, Microporous Mesoporous Mater., 2019, 280, 88-96.

[21] J. Zhang, C. Zhao, ACS Catal., 2016, 6, 4512-4525.

[22] Y. Lu, B. Ma, C. Zhao, Chem. Commun., 2018, 54, 9829-9832

[23] H. Jin, X. Feng, J. Li, M. Li, Y. Xia, Y. Yuan, J. Lu, Angew. Chem. Int. Ed., 2019, 58, 2397-2401.

[24] Y. Deng, Y. Ji, H. Wu, F. Chen, Chem. Commun., 2019, 55, 1486-1489.

[25] J. Shi, M. Zhao, Y. Wang, J. Fu, X. Lu, Z. Hou, J. Mater. Chem. A, 2016, $4,5842-5848$.

[26] J. Li, J. Zhang, S. Wang, G. Xu, H. Wang, D. G. Vlachos, ACS Catal., 2019, 9, 1564-1577.

[27] S. Lestari, P. Maki-Arvela, H. Bernas, O. Simakova, R. Sjöholm, J. Beltramini, D. Y. Murzin, Energy Fuels, 2009, 23, 3842-3845.

[28] S. Lestari, I. Simakova, A. Tokarev, P. Mäki-Arvela, K. Eränen, D. Y. Murzin, Catal. Lett., 2008, 122, 247-251.
[29] Q. Tian, Z. Zhang, F. Zhou, K. Chen, J. Fu, X. Lu, P. Ouyang, Energy Fuels. 2017, 31, 6163-6172.

[30] J. Deng, T. Xiong, F. Xu, M. Li, C. Han, Y. Gong, Y. Wang, Green Chem., 2015, 17, 4053-4060.

[31] X. Hu, X. Sun, S. J. Yoo, B. Evanko, F. Fan, S. Cai, G. D. Stucky, Nano Energy, 2019, 56, 828-839.

[32] Z. Luo, Q. Bing, J. Kong, J. Y. Liu, C. Zhao, Sci. Technol., 2018, 8, 1322-1332.

[33] B. Li, L. Li, C. Zhao, Green Chem., 2017, 19, 5412-5421.

[34] V. Budarin, J. H. Clark, J. J. Hardy, R. Luque, K. Milkowski, S. J. Tavener, A. J. Wilson, Angew. Chem. Int. Ed., 2006, 45, 3782-3786.

[35] Y. Meng, D. Voiry, A. Goswami, X. Zou, X. Huang, M. Chhowalla, T. Asefa, J. Am. Chem. Soc., 2014, 136, 13554-13557.

[36] L. Shen, L. M. Peng, Chin. J. Catal., 2015, 36, 1494-1504.

[37] L. Gao, T. J. McCarthy, Langmuir, 2006, 22, 6234-6237.

[38] F. Taherian, V. Marcon, N. F. van der Vegt, F. Leroy, Langmuir, 2013, 29, 1457-1465.

[39] A. Ali, B. Li, Y. Lu, C. Zhao, Green Chem., 2019, 21, 3059-3064.

[40] G. Xu, Y. Zhang, Y. Fu, Q. Guo, ACS Catal., 2017, 7, 1158-1169.

[41] E. Wilhelm, R. Battino, R. J. Wilcock, Chem. Rev., 1977, 77, 219-262.

[42] V. I. Baranenko, V. S. Kirov, At. Energy, 1989, 66, 30-34.

[43] Z. Luo, W. Wang, M. He, C. Zhao, Green Chem., 2016, 18, 433-441.

[44] G. Jerkiewicz, Electrocatalysis, 2010, 1, 179-199.

[45] V. Subramanian, C. Luo, A. M. Stephan, K. S. Nahm, S. Thomas, B. Wei, J. Phys. Chem., 2007, 111, 7527-7531.

[46] E. Thompson, A. E. Danks, L. Bourgeois, Z. Schnepp, Green Chem., 2015, 17, 551-556.

[47] A. Corma, H. Garcia, Chem. Rev., 2013, 103, 4307-4366.

\title{
亲水性介孔碳负载Ru纳米粒子催化海藻油低温水相加氢脱氧制烷烃
}

\author{
林凯 ${ }^{\mathrm{a}}$, 赵晨 ${ }^{\mathrm{a}, \mathrm{b}, *}$ \\ a华东师范大学化学与分子工程学院, 上海市绿色化学与化工过程绿色化重点实验室, 上海200062 \\ b华东师范大学崇明生态研究院, 上海 200062
}

摘要: 将微藻油等能源载体加工成有价值的燃料和化学品具有广阔的应用前景. 由于从藻类细胞中分离固有水非常困难, 因此以水相为溶剂适合含水微藻油的转化. 而制备耐水且水热稳定的催化剂非常重要, 因为许多载体容易被蒸汽破坏. 其 中, 碳材料相当稳定, 具有高的比表面积. 然而, 它们具有高度的憎水性, 亲水性较差, 因此很难与水中的反应物接触.

本文中, 我们合成了以高度亲水性介孔碳为载体的钉/碳催化剂, 用于催化微藻油在低温 $\left(140^{\circ} \mathrm{C}\right)$ 下一锅法于水相中定 量加氢脱氧成烷烃. 首先以淀粉和氯化锌为原料, 在氮气中一步殷烧制备了介孔炭. 其中, 淀粉用作碳源, 氯化锌则作为活 化的路易斯酸和脱水剂. 所得碳具有高的比表面积和孔体积, 使得Ru纳米粒子具有较高的分散性. XPS表征表明, Ru/AC 在 $286.5 \mathrm{eV}$ 处有一个与杂原子结合的 $s p^{2}$ 碳峰, 表明催化剂上存在 $\mathrm{C}-\mathrm{OH}$ 基团. 值得注意的是, $\mathrm{Ru} / \mathrm{C}-\mathrm{ZnCl}_{2}$ 催化剂在 $286.5 \mathrm{eV}$ 时的峰值比 $\mathrm{Ru} / \mathrm{AC}$ 催化剂的峰值更强, 显示 $\mathrm{Ru} / \mathrm{C}-\mathrm{ZnCl}_{2}$ 表面有更多的 $\mathrm{C}-\mathrm{OH}$ 键. FTIR光谱研究表明, 两种催化剂分别在 3400 和 $1530 \mathrm{~cm}^{-1}$ 处出现对应于 $\mathrm{O}-\mathrm{H}$ 拉伸和 $\mathrm{C}=\mathrm{C}$ 键的振动峰. 有趣的是, $\mathrm{Ru} / \mathrm{C}-\mathrm{ZnCl}_{2}$ 催化剂在 $1092 \mathrm{~cm}^{-1}$ 处显示出强且宽的峰证实 了羟基的存在. 但在 $\mathrm{Ru} / \mathrm{AC}$ 催化剂中没有观察到该峰. 催化剂的热重分析显示, 在低于 $100{ }^{\circ} \mathrm{C} 、 120-579{ }^{\circ} \mathrm{C}$ 和 $580{ }^{\circ} \mathrm{C}$ 的温度 下分别出现三个峰, 分别对应于脱水(表面水分)、去除含氧基团和载体分解. $\mathrm{Ru} / \mathrm{C}-\mathrm{ZnCl}_{2}$ 催化剂的失重率(13\%) 是 $\mathrm{Ru} / \mathrm{AC}(3 \%)$ 的4倍, 与FTIR测试结果一致, 表明 $\mathrm{Ru} / \mathrm{C}-\mathrm{ZnCl}_{2}$ 催化剂上的羟基含量较高. XPS、IR和TGA结果表明, 碳材料表面 富含羟基. 另一方面, 对 $\mathrm{Ru} / \mathrm{C}-\mathrm{ZnCl}_{2}$ 和 $\mathrm{Ru} / \mathrm{AC}$ 催化剂进行了与水的接触角实验, 通过比较 $\mathrm{Ru} / \mathrm{C}-\mathrm{ZnCl}_{2}$ 和 $\mathrm{Ru} / \mathrm{AC}$ 与水的不同作 用角, 进一步证实了 $\mathrm{Ru} / \mathrm{C}-\mathrm{ZnCl}_{2}$ 比 $\mathrm{Ru} / \mathrm{AC}$ 具有更好的亲水性. 我们认为, 碳材料相对于有机相优选地与水相接触, 提高了基 底的可接近性. 同样, 亲水性碳材料由于其水相容性而更适合于水相反应.

催化剂对硬脂酸的反应结果显示, $\mathrm{Ru} / \mathrm{AC}$ 催化剂转化率为 $100 \%$, 硬脂醇收率 $52 \%$, 正庚烷收率 $43 \%$, 酯收率 $3 \%$. 而 $\mathrm{Ru} / \mathrm{C}-\mathrm{ZnCl}_{2}$ 催化剂的硬脂酸转化率为 $100 \%$, 正庚烷产率为 $88 \%$, 正十八烷产率为 $12 \%$. 原位FTIR研究了模型化合物丁酸在 两种钓/碳催化剂上的吸附和加氢脱氧作用. 实验结果表明, 丁酸在 $\mathrm{Ru} / \mathrm{C}-\mathrm{ZnCl}_{2}$ 催化剂上显现了 $1720 \mathrm{~m}^{-1}$ 处丁酸的羰基振动 峰, 这是由于其多孔性和对丁酸的吸附. 相比之下, Ru/AC催化剂在 $1720 \mathrm{~cm}^{-1}$ 处未见出峰显示对丁酸的弱吸附. 总之, 在硬 
脂酸的串联加氢和脱羰反应中, 亲水性介孔和亲水性 $\mathrm{Ru} / \mathrm{C}-\mathrm{ZnCl}_{2}$ 催化剂的动力学模拟和在水中的原位红外监测均显示出 比商用 $\mathrm{Ru} / \mathrm{AC}$ 催化剂优越的性能. 本文设计的水热碳材料是一种高活性、环境友好、可持续、可循环利用的材料, 在水热 条件下的加氢反应中表现出很好的应用潜力.

关键词: 海藻油; 硬脂酸; 十七烷; 亲水性碳材料; 加氢脱氧; $\mathrm{Ru} / \mathrm{C}$ 催化剂

收稿日期: 2019-11-28. 接受日期: 2019-12-23. 出版日期: 2020-08-05.

*通讯联系人. 电子信箱: czhao@chem.ecnu.edu.cn

基金来源：国家重点研发计划(2016YFB0701100); 国家自然科学基金(21573075); 华东师范大学崇明生态研究院 (ECNU-IEC-201902).

本文的电子版全文由Elsevier出版社在ScienceDirect上出版(http://www.sciencedirect.com/science/journal/18722067). 